\title{
In vitro establishment and early development of barueiro (Dipteryx alata Vogel)
}

\author{
Estabelecimento in vitro e desenvolvimento inicial de barueiro \\ (Dipteryx alata Vogel)
}

\author{
Herick Fernando de Jesus Silva ${ }^{1 *}$; Simone Abreu Asmar²; Rayssa Camargo de \\ Oliveira $^{1}$; Berildo de Melo ${ }^{3}$; José Magno Queiroz Luz ${ }^{3}$; Moacir Pasqual ${ }^{4}$
}

\begin{abstract}
The barueiro (Dipteryx alata Vog.) is a native fruit species of the Cerrado ecoregion that has multiple uses. It is a wild species, and its cultivation is difficult. Furthermore, it is threatened with extinction. Plant tissue culture is a major tool for the conservation of germplasm, as well as a means of propagating highquality seedlings on a large scale. However, this technique has not been used with barueiro, although it might provide valuable contributions to the process of barueiro domestication. The most popular method of cultivation is the use of the Murashige and Skoog medium (MS), which is considered one of the most nutritionally complete media. Woody plant medium (WPM) is indicated for the propagation of woody species, but there are no reports of its use for barueiro cultivation. Woody plants tend to have problems with rust in vitro during the establishment phase. Activated charcoal acts as an adjuvant for the adsorption of phenolic compounds, mitigating its effects in the medium. Thus, the objective of this study was to test four activated charcoal doses $\left(0,2,4\right.$ and $\left.6 \mathrm{~g} \mathrm{~L}^{-1}\right)$ and three culture media: MS, WPM, and AA (over water agar) in the in vitro establishment of barueiro. The experimental design was a completely randomised (DIC), $4 \times 3$ factorial design with three replications. At 60 days after inoculation, the explants were evaluated for dry matter, fresh weight, stem diameter, shoot length, number of leaves, longest root length, germination rate, and chlorophyll contents. The MS medium supplemented with 3,0 $\mathrm{g} \mathrm{L}^{-1}$ activated charcoal appeared to be the best for in vitro establishment of barueiro.
\end{abstract}

Key words: Native fruit. Activated charcoal. Culture medium.

\section{Resumo}

O barueiro (Dipteryx alata Vog.) é uma espécie frutífera nativa do Cerrado que possui múltiplas possibilidades de utilização. Por estar em estado praticamente selvagem, seu cultivo é dificultado. Além disso, encontra-se ameaçada de extinção. A cultura de tecidos vegetais constitui uma importante ferramenta para a conservação de germoplasma, além de proporcionar a rápida propagação de mudas de qualidade em larga escala. Porém, esta técnica não vem sendo utilizada em barueiro, mas pode ser aplicada de forma valiosa contribuindo para seu processo de domesticação. O meio de cultivo mais utilizado é o MS, considerado um dos mais completos nutricionalmente. O meio WPM é indicado para a propagação de espécies lenhosas, porém não há relatos da sua utilização para o cultivo do barueiro.

${ }^{1}$ Eng $^{\text {os }}$ Agr $^{\text {os }}$, Discentes do Curso de Doutorado do Programa de Pós-Graduação em Agronomia, Universidade Federal de Uberlândia, UFU, Uberlândia, MG, Brasil. E-mail: herickfernando@gmail.com; rayssacamargo@yahoo.com.br

${ }^{2}$ Eng $^{\mathrm{a}}$ Agr ${ }^{\mathrm{a}}$, Bolsista Pós-Doutorado, CAPES-Embrapa, UFU, Uberlândia, MG, Brasil. E-mail: siasmar@yahoo.com.br

${ }^{3}$ Eng ${ }^{\text {os }}$ Agros , Profs., Curso de Pós-Graduação em Agronomia, UFU, Uberlândia, MG, Brasil. E-mail: berildo@ufu.br; jmagno@ umuarama.ufu.br

${ }^{4}$ Eng $^{\circ}$ Agr $^{\circ}$, Prof., Curso de Pós-Graduação em Agronomia, Universidade Federal de Lavras, UFLA, Lavras, MG, Brasil. E-mail: mpasqual@dag.ufla.br

* Author for correspondence 
Plantas lenhosas apresentam grandes problemas com oxidação em fase de estabelecimento in vitro. O carvão ativado atua como coadjuvante na adsorção desses compostos fenólicos, atenuando os seus efeitos no meio. Diante disso, o objetivo desse trabalho foi testar quatro doses de carvão ativado $(0,2$, 4 e $6 \mathrm{~g} \mathrm{~L}^{-1}$ ) e três meios de cultivo: MS, WPM e AA (água mais ágar), no estabelecimento in vitro de barueiro. O delineamento experimental utilizado foi o inteiramente casualizado (DIC), esquema fatorial 4x3, com três repetições. Aos 60 dias após a inoculação dos explantes foram avaliados: massa seca, massa fresca, diâmetro do caule, comprimento da parte aérea, número de folhas, comprimento da maior raiz, taxa de germinação e teores de clorofilas. O meio MS acrescido de $3,0 \mathrm{~g} \mathrm{~L}^{-1}$ de carvão ativado mostra-se mais promissor para o estabelecimento in vitro de barueiro.

Palavras-chave: Fruteira nativa. Carvão ativado. Meio de cultura.

\section{Introduction}

Brazilian Cerrado, with its 204 million hectaresapproximately $25 \%$ of the national territoryhas a diversity of fauna and flora in its various vegetation types (ROCHA, 2009). The vegetation contains of numerous plant species with properties that make them prone to exploitation by man (BLUMENSCHEIN; CALDAS, 1995).

The barueiro is a fruit species of the Cerrado ecoregion with multiple uses, including utilisation as food, in which the consumption of their seeds is preferable (ALMEIDA et al., 1998). This species can also be used in the timber industry, landscape architecture, and land reclamation (SILVÉRIO et al., 2013).

According to Martinelli and Moraes (2013), the barueiro is endangered because of the uncontrolled exploitation of the species, loss of native forests, and the increase in monoculture agriculture and urbanisation. Associated with this problem, Junqueira et al. (2012) stated that most of the fruits with superior features have been extracted in order to meet consumer demands. This contributed to genetic erosion and the natural perpetuation of inferior genetic material. Based on these issues, it is important to elucidate the techniques that can facilitate the in vitro cultivation of this species, which would ensure the large-scale production of plants, germplasm conservation, and effective breeding programs. Thus, plant tissue culture could be a valuable technique in this respect. However, there are no micropropagation protocols for this species.

The Murashige and Skoog (MS) medium (MURASHIGE; SKOOG, 1962) is currently used for a large number of species because of its nutritional complexity. The woody plant medium (WPM) (LLOYD; McCOWN, 1981) has wide applicability for the propagation of woody plants. Thus, these two formulations are the most promising for in vitro establishment of barueiro.

Oxidation is one of the common limitations of in vitro cultivation of woody species (KERBAUY, 2004). This process results in the release of phenolics, which are in vitro precursors of lignin synthesis in the injured tissue (VAN WINKLE et al., 2003). These phenolic compounds undergo oxidation by polifenase enzymes, producing toxic compounds that inhibit the growth of the explants, frequently resulting in their death (SATO et al., 2001).

The application of activated charcoal to the culture medium has the ability to adsorb toxic substances, other components, or impurities released by explants (GRATTAPAGLIA; MACHADO, 1998). George and Ravishankar (1997) stated that activated charcoal further attenuates the light interception in the culture medium, stimulating rooting. However, this antioxidant has no selective effect, which might induce androgyny, alter $\mathrm{pH}$, and remove organic nutrients and plant growth regulators, thereby inhibiting growth and morphogenesis (ARDITTI; ERNST, 1992; GEORGE, 1993; PAN; STADEN, 1998; SANTOS-SEREJO et al., 2006). Thus, the concentration of the additive in the culture medium should be adjusted to provide maximum efficiency, while minimising the antagonistic effects on the species that might significantly influence the development of explants. 
Concern for the conservation of genetic resources of native species, such as the barueiro, which is currently endangered, emphasises the need for the establishment of micropropagation protocols involving this species. Given the above, the goal of this study was to determine the most suitable culture medium for the in vitro establishment and early development of barueiro, including the inhibition of non-phenolic oxidation through different activated charcoal concentrations.

\section{Material and Methods}

The study was conducted between January and February 2014 in the Biotechnology Laboratory of the Institute of Agricultural Sciences (ICIAG) of the Federal University of Uberlândia. The ripe fruit of barueiros were collected from trees located in the rural town of Uberlândia MG $\left(18^{\circ} 45^{\prime} 13.8^{\prime \prime} \mathrm{S}\right.$, $\left.48^{\circ} 18^{\prime} 09.6^{\prime \prime} \mathrm{E}\right)$.

The seeds were removed from the fruit with the use of a benchtop vice, which caused a slight break in the fruit endocarp that break did not extent to or expel the seed. Next, the seeds went through a sterilisation process that consisted of being washed with neutral detergent in tap water for five min, immersed in ethanol $70 \% \mathrm{v} / \mathrm{v}$ for two min, and subsequently, soaked to a $2 \% \mathrm{v} / \mathrm{v}$ sodium hypochlorite solution while being stirred for $30 \mathrm{~min}$. This disinfestation procedure was based on the best results during pretests. At the end of this process, the seeds underwent a triple washing in distilled water, were autoclaved in a laminar flow hood, and were inoculated into $150-\mathrm{mL}$ glass vials containing $40 \mathrm{~mL}$ of culture medium. A total of $6.5 \mathrm{~g} \mathrm{~L}^{-1}$ agar Dinâmica ${ }^{\circledR}$ was added to all media, and the $\mathrm{pH}$ was adjusted to 5.7 before autoclaving.

Treatments consisted of three different culture media, MS (MURASHIGE; SKOOG, 1962), WPM (LLOYD; McCOWN, 1981), and AA (water more agar), and four activated charcoal concentrations $(0$, 2, 4 and $\left.6 \mathrm{~g} \mathrm{~L}^{-1}\right)$. The experiment was conducted in a completely randomised design in a $3 \times 4$ factorial design (12 treatments) with three replications, totalling 36 experimental units. Each experimental unit consisted of 10 bottles with a seed in each.

For seed inoculation, the flasks were placed in a growth chamber maintained at a temperature of $25^{\circ} \mathrm{C} \pm 1^{\circ} \mathrm{C}$ with a photoperiod of $16 \mathrm{~h}$ light provided by cool white fluorescent lamps that provided a luminous intensity of $25 \mu \mathrm{mol} \mathrm{m} \mathrm{m}^{-2} \mathrm{~s}^{-1}$.

After 60 days in the growth room, the following characteristics were assessed: germination rate (seeds were considered germinated if they possessed a visible and developed radicle or plumule) (\%); shoot length $(\mathrm{cm})$, longest root $(\mathrm{cm})$, dry weight $(\mathrm{g})$, fresh weight $(\mathrm{g})$, stem diameter $(\mathrm{mm})$, number of leaves, and chlorophyll A, B, and total levels ( $\mu \mathrm{g}$ $\mathrm{cm}^{-3}$ ) as determined by the ClorofiLOG ${ }^{\circledR}$ portable meter, model CFL 1030 (FALKER AUTOMAÇÃO AGRÍCOLA LTDA, 2008).

The data were submitted to an analysis of variance (ANOVA) using the computer program SISVAR (FERREIRA, 2010) and means were compared by the Tukey test at $5 \%$ probability of error. Before analysis, the normality of the residuals and homogeneity of variances were tested with the Shapiro-Wilk test $(\alpha=0.01)$ and Levene's test ( $\alpha$ $=0.01)$, respectively, using the SPSS computer program.

\section{Results and Discussion}

The ANOVA (Table 1) revealed a significant interaction between fresh mass (MF) and stem diameter (DIA). Interactions were not significant for dry matter (MSC), shoot length (CPA), length of root (CR), germination percentage (GER), and A (CA), B (CB), and total chlorophyll (CT). This indicated that the factors studied were independent and could be analysed separately. The number of leaves (NL) has the unique feature that did not differ between treatments (Table 1), and the average ranged from 21.61 to 22.65 . 
Table 1. Summary of the variance in the characteristics, including dry mass (MSC), fresh mass (MF), shoot length (CPA), length of root (CR), stem diameter (DIA), number of leaves (NL), \% germination (GER), and chlorophyll content A (CA), B (CB), and total (CT), of barueiro (Dipteryx alata Vog.) seedlings cultivated in vitro in three nutrient media and four doses of activated charcoal.

\begin{tabular}{llllllllllll}
\hline FV & GL & MSC & MF & CPA & CR & DIA & NL & GER & CA & CB & CT \\
\hline Medium & 2 & $1,31^{\text {ns }}$ & $11,00^{*}$ & $2,90^{\text {ns }}$ & $11,95^{*}$ & $6,11^{\text {ns }}$ & $0,39^{\text {ns }}$ & $1,37^{\text {ns }}$ & $5,94^{*}$ & $5,47^{*}$ & $6,24^{*}$ \\
Charcoal & 3 & $7,92^{*}$ & $10,00^{*}$ & $3,75^{*}$ & $6,86^{*}$ & $2,89^{\text {ns }}$ & $1,41^{\text {ns }}$ & $10,28^{*}$ & $0,91^{\text {ns }}$ & $0,74^{\text {ns }}$ & $0,86^{\text {ns }}$ \\
MediumxCharcoal & 6 & $1,22^{\text {ns }}$ & $2,58^{*}$ & $0,515^{\text {ns }}$ & $1,86^{\text {ns }}$ & $3,93^{*}$ & $0,16^{\text {ns }}$ & $0,93^{\text {ns }}$ & $0,27^{\text {ns }}$ & $1,70^{\text {ns }}$ & $1,12^{\text {ns }}$ \\
CV $(\%)$ & & 8,28 & 10,36 & 8,39 & 16,89 & 7,21 & 14,56 & 14,28 & 4,55 & 20,37 & 9,11 \\
Overall average & & 0,70 & 3,06 & 16,41 & 25,84 & 4,22 & 22,29 & 79,16 & 44,09 & 21,70 & 65,80 \\
\hline
\end{tabular}

*Significant at $5 \%$ probability by the $\mathrm{F}$ test, ${ }^{\mathrm{ns}}$ not significant by $\mathrm{F}$ test.

Fresh mass (MF) of barueiro seedlings exhibited a linear behaviour in both the MS and WPM media, indicating the gradual increase in activated carbon doses favoured a gain in biomass in these plants (Figure 1). As for the AA medium, no polynomial regression model fit the data. Consequently, no chart was created to represent the fresh mass for this treatment. The absorbance of toxic substances by activated charcoal can only be promoted to a point, to avoid the interference of charcoal in the biomass gain by the plantlet. Results of this study were consistent with those found in the development of citrus embryos cultured in vitro (RIBEIRO et al., 2000), where the higher doses of activated charcoal were those that favoured the largest increments of growth of the shoot and root system.

Figure 1. Fresh mass (g) of barueiro (Dipteryx alata Vog.) seedlings at different doses of activated charcoal in the MS and WPM culture medium.

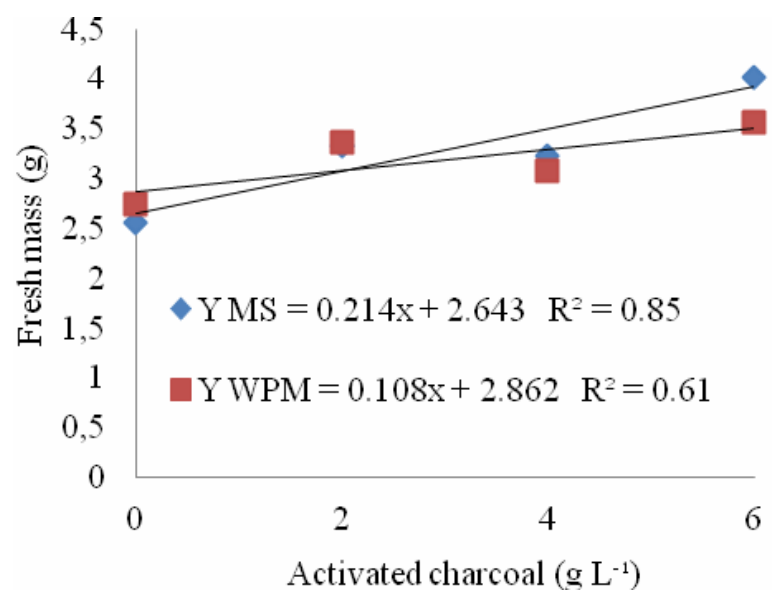

Woody species normally undergo oxidation in tissues; this oxidation is caused by the presence of secondary metabolites that are normally found in cells with active growth (OZYIGIT et al., 2007). Moreover, the presence of these substances may be maximised during disinfection primarily because of the presence of chlorine in disinfectants agents.
Chlorine has high oxidising power, and high chlorine levels are toxic (SILVA et al., 2015). This reinforces the importance of activated charcoal in the culture medium.

Until the dose of $4 \mathrm{~g} \mathrm{~L}^{-1}$, the variable MF was equal for all culture media tested. The treatments 
above $6 \mathrm{~g} \mathrm{~L}^{-1}$ of activated charcoal alone were superior to the MS and WPM media (Table 2). The higher concentration of activated charcoal $\left(6 \mathrm{~g} \mathrm{~L}^{-1}\right)$ in the culture medium that was free of nutrients (water + agar) could be disadvantageous to the developing plantlet because of the adsorbent effect exerted by the additive. Under these conditions, the additive probably absorbed reserves from the endosperm of explants.

Table 2. Average fresh weight (g) of barueiro (Dipteryx alata Vog.) seedlings in three nutrient culture media and four doses of activated charcoal during in vitro establishment.

\begin{tabular}{ccccc}
\hline & \multicolumn{4}{c}{ Activated Charcoal $\left(\mathbf{g ~ L}^{-1}\right)$} \\
\hline Nutrient Medium & $\mathbf{0}$ & $\mathbf{2}$ & $\mathbf{4}$ & $\mathbf{6}$ \\
\hline AA & $2.54 \mathrm{~A}$ & $2.86 \mathrm{~A}$ & $2.84 \mathrm{~A}$ & $2.64 \mathrm{~B}$ \\
MS & $2.56 \mathrm{~A}$ & $3.33 \mathrm{~A}$ & $3.08 \mathrm{~A}$ & $3.57 \mathrm{~A}$ \\
WPM & $2.74 \mathrm{~A}$ & $3.37 \mathrm{~A}$ & $3.23 \mathrm{~A}$ & $4.02 \mathrm{~A}$ \\
\hline CV $=10.36 \% ;$ LSD $=0.32$ & \multicolumn{5}{c}{} \\
\hline
\end{tabular}

Means followed by the same capital letter in a column do not differ by Tukey test at $5 \%$ probability; CV: coefficient of variation; LSD: least significant difference.

Similar behaviour was observed for stem diameter (DIA) (Table 3), reinforcing the hypothesis that in conditions devoid of salts in the culture medium, charcoal competes with the natural reserves of seedlings. In explants of citrus hybrids, activated charcoal favoured positive results in the fresh weight of seedlings; however, the explants began to require higher concentration of $\mathrm{GA}_{3}$, a fact that points to interference of the additive in the assimilation of this phytoregulator (CHAGAS et al.,
2005). Several authors have concluded that despite the beneficial effect of activated charcoal, including the absorption of toxic components and medium impurities, it also acts on the useful agents, such as sucrose, salts, and in some cases growth regulators, making them inactive or unavailable for the explant. Thus, they suggest that concentrations between $0.1 \%$ and $2.0 \%$ are within the desirable range for the safe application of this component (BOULAY, 1964; CHAGAS et al., 2005; GRATTAPAGLIA; MACHADO, 1998; RICCI et al., 2002).

Table 3. Average diameter ( $\mathrm{mm}$ ) of barueiro (Dipteryx alata Vog.) seedlings in three nutrient culture and media four doses of activated charcoal during in vitro establishment.

\begin{tabular}{lcccc}
\hline & \multicolumn{4}{c}{ Activated Charcoal $\left(\mathbf{g ~ L}^{-\mathbf{1}}\right)$} \\
\hline Nutrient Medium & $\mathbf{0}$ & $\mathbf{2}$ & $\mathbf{4}$ & $\mathbf{6}$ \\
\hline AA & $3.53 \mathrm{~B}$ & $4.68 \mathrm{~A}$ & $4.15 \mathrm{~A}$ & $3.82 \mathrm{~B}$ \\
MS & $4.43 \mathrm{~A}$ & $4.51 \mathrm{AB}$ & $4.27 \mathrm{~A}$ & $4.64 \mathrm{~A}$ \\
WPM & $4.10 \mathrm{AB}$ & $4.00 \mathrm{~B}$ & $3.99 \mathrm{~A}$ & $4.53 \mathrm{~A}$ \\
\hline CV $=7.21 \% ; \mathrm{LSD}=0.31$ & \multicolumn{4}{c}{} \\
\hline
\end{tabular}

Means followed by the same capital letter in a column do not differ by Tukey test at $5 \%$ probability; CV: coefficient of variation; LSD: least significant difference. 
With increasing charcoal concentrations, there was an increase in stem diameter (DIA) (Figure 2) that followed the quadratic model. For stem diameter, we found it followed the polynomial regression model only for the AA medium. In this culture, medium levels above $3 \mathrm{~g} \mathrm{~L}^{-1}$ of activated charcoal were detrimental to the increase in stem diameter. Given the efficiency of activated carbon to adsorb undesirable compounds, which are occasionally present in the medium, it follows that it also acts on the desirable substances, making them unavailable for the explant, indicating there is a tolerable limit for this agent to the culture medium. The optimal dose in this study was approximately $2,5 \mathrm{~g} \mathrm{~L}^{-1}$, a result that corroborates those found by Chagas et al. (2005) and Schneiders et al. (2012) who worked with Cattleya harrisoniana and several species of citrus, respectively. An adequate supply of activated charcoal is an essential requirement for the satisfactory performance of explants in vitro.

Figure 2. Mean diameter of the stems of barueiro (Dipteryx alata Vog.) seedlings grown in AA medium (water + agar) with different activated charcoal concentrations.

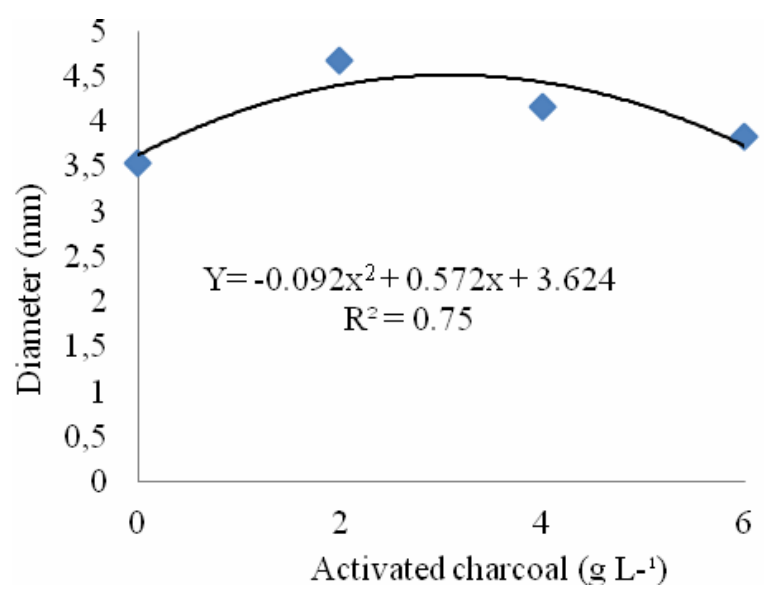

For germination percentage (Figure 3A), similar behaviour was observed with a variable stem diameter. A maximum dose occurred, where the germination rate was enhanced proportionally. Until the approximate concentration of $4,7 \mathrm{~g} \mathrm{~L}^{-1}$, activated charcoal enabled the rate and it reached a maximum of $88 \%$. Higher doses of the additive were unfavourable to this biological process, and germination percentage began to decrease proportionally. Responses obtained in this study support the hypothesis that the addition of activated charcoal in the culture medium can promote or inhibit growth in vitro, depending on the concentration used (PAN; STADEN, 1998). In Hancornia speciosa (LÉDO et al., 2007), for example, a charcoal dose of $2 \mathrm{~g} \mathrm{~L}^{-1}$ added to the culture medium provided

$100 \%$ germination, implying that the concentration of the additive has a great influence during the establishment phase. The highest concentration of activated charcoal maximised dry mass gains (MSC), shoot length (CPA), and the longest root length (CR) (Figure 3B, 3C and 3D). Activated charcoal is one of the compounds used to induce root formation in vitro, and it aids in the adsorption of excess toxic substances in the culture medium, such as phenols and growth regulators. It also reduces in the incidence of light in the active growth zone of the root system, which stimulates the formation and lengthening of roots (BONGA, 1985) as they search for light (NUNES et al., 2008). This principle explains the linearly positive action of the expansion of the roots of barueiros. Similar activity 
of activated charcoal was found in the length of the stem and root system of hybrid embryos of Citrus limonia Osb. x Poncirus trifoliata (L.) Raf., which exhibited a positive correlation with these variables and dosages of activated charcoal (RIBEIRO et al., 2000). Data from this study further supported those obtained by Lédo et al. (2007) and Gomes et al. (2010) who had better root development for mangabeira plants (Hancornia speciosa) and the explant Maclura tinctoria, respectively, when cultured in vitro.

Figure 3. Germination rate (A), dry mass (B), shoot length (C), and length of roots (D) of barueiro (Dipteryx alata Vog.) seedlings grown in different activated charcoal concentrations.

(A)

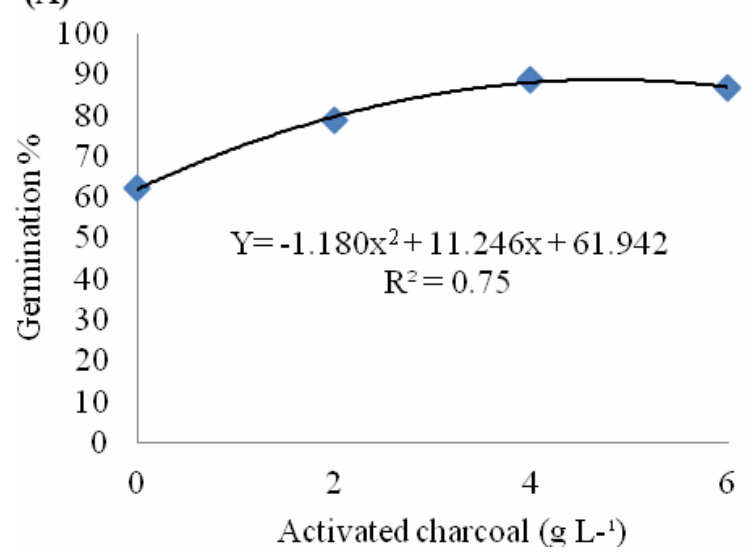

(C)

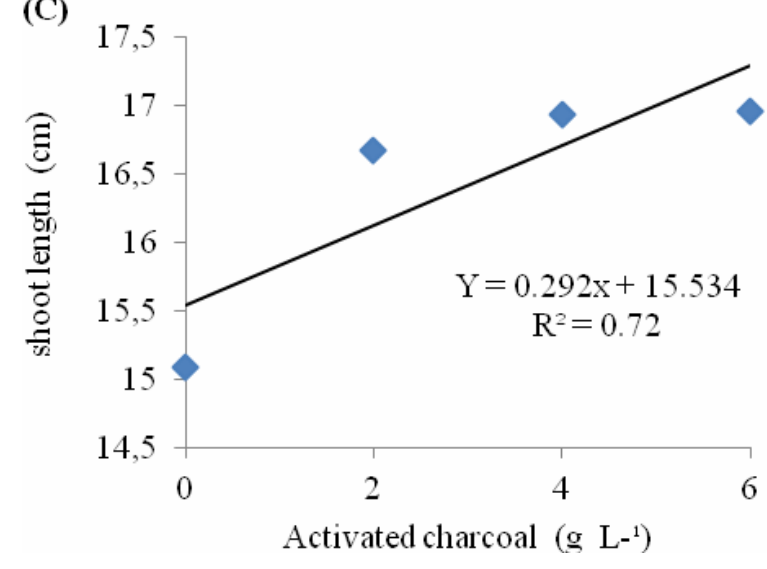

It is evident that activated charcoal is important in the development of vegetative structures because dose and growth are positively correlated. In addition, visually it was found that there were a large percentage of seedlings with abnormal development or deficient organs in the absence of this antioxidant. The delay in development of explants of woody species because of oxidation was also reported in cupuçuazeiro (Theobroma grandiflorum Schum)
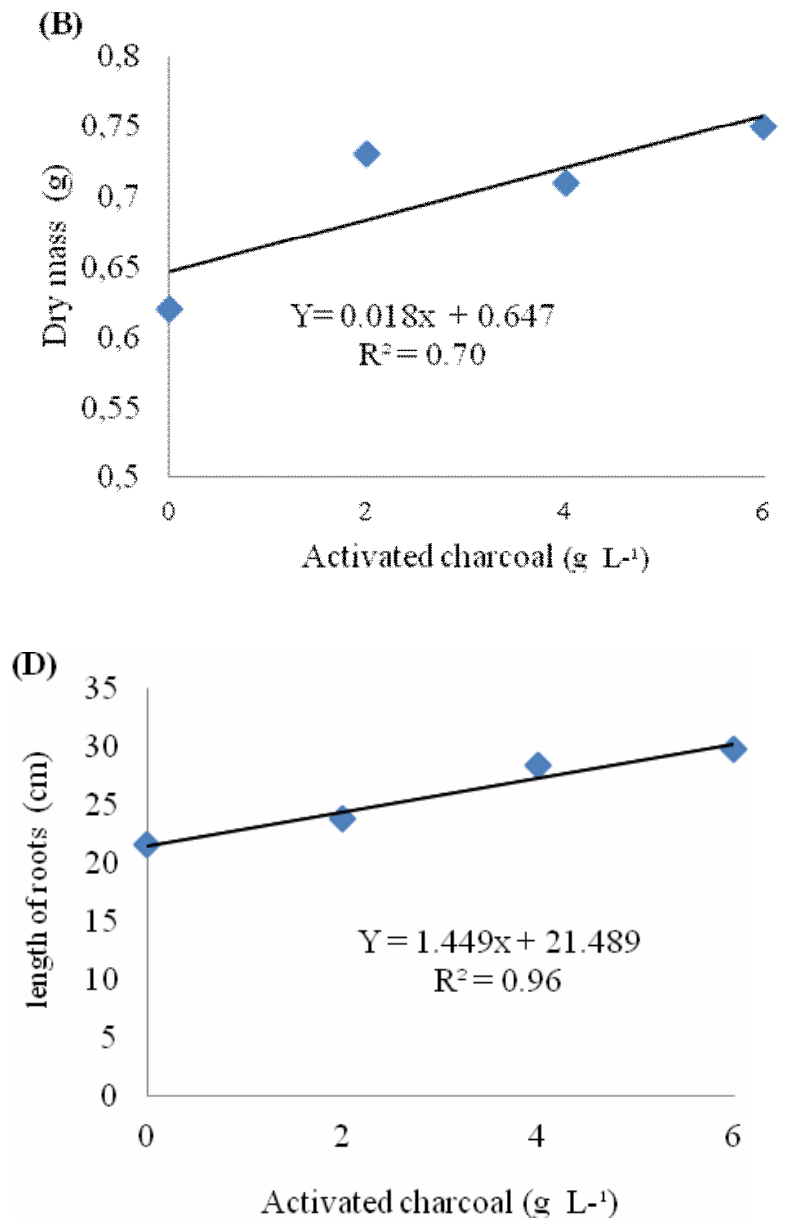

(LÉDO et al., 2002). The importance of activated charcoal in the micropropagation of native species is further reinforced by work done with mangabeira (Hancornia speciosa Gomes) and araticunzeiro (Annona glabra L.) (LÉDO et al., 2007; SANTANA et al., 2011).

It is important to note that there was synchronic development of the shoot and the increase in dry mass with the development of the root system of 
the seedlings in all treatments. Thus, it appears that activated charcoal provided better root development and indirectly produced benefits to other parts of the seedlings. According to Peres and Kerbauy (2000), this balance between stem and roots is advantageous considering that both have complementary functions in general plant survival. Note that the MS medium produced less development of the longest root in comparison to WPM and AA, which were remarkable for this variable (Figure 4).

Figure 4. Average length $(\mathrm{cm})$ of the largest root of barueiro (Dipteryx alata Vog.) seedlings in three nutritional media during in vitro culture.

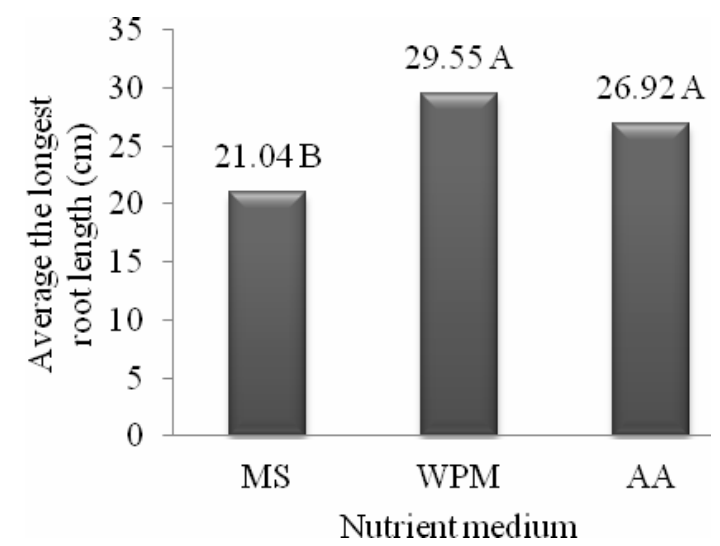

Means followed by the same letter do not differ by Tukey test at $5 \%$ probability; $\mathrm{CV}=16.89 \%$.

The MS medium contained high concentrations of nitrogenous salts in its composition as compared to the other culture media. Thus, the full MS medium proved inadequate for the rooting procedure of $D$. alata. The same negative effect was observed in the regeneration of nodal segments of $A$. othonianum Rizz. (ASSIS et al., 2012). This may be an indication that native Cerrado species, because they are adapted to poor soils, tend to develop better by artificial means that simulate their natural conditions. Importantly, during the in vitro culture, the solutions of salts and sugars that make up the culture media did not exercise a purely nutritional effect, but also influence cell growth and morphogenesis through osmotic properties (GEORGE, 1993; MALDANER et al., 2006). As Taiz and Zeiger (2004) stated, very high osmotic pressure limits the absorption of water, and the dilution by water increases availability and reduces oxygenation. The absolute concentration of a nutrient medium is not always the most appropriate for a given species. During in vitro cultivation of genipapapeiro (Genipa americana) and cerejeira (Amburana acreana), for example, germination was not favoured when concentrations of MS salts increased (ALMEIDA et al., 2013; FERMINO JÚNIOR; PEREIRA, 2012). For ingazeiro (Inga vera Willd. subsp. affinis), a higher percentage of germination in occurred in WPM/2 (STEIN et al., 2007). Therefore, the use of different compositions of culture medium produces specific responses.

Russowski and Nicoloso (2003) studied the effect of variation of $\mathrm{N}$ and $\mathrm{P}$ in the MS medium in the development of Brazilian ginseng (Pfaffia glomerata (Spreng.) Pedersen). They found that the number of roots and rooting percentage was higher in the concentration of $\mathrm{N}$ equivalent to $50 \%$ of that of the original MS medium. With woody species, MS means are unsatisfactory in some cases, and a more diluted composition of macronutrients performs better (GRATTAPAGLIA; MACHADO, 
1998). Thus, the adjustment of concentration of these salts is important for each species, seeking the optimisation of appropriate protocols for each.

For the Falker Index, the contents of A, B, and total chlorophyll were higher in treatments supplied with MS medium, based on the comparison with the WPM, which exhibited lower results for these variables (Table 4). These results were similar to those found with Aspasia variegata, wherein the MS media produced higher levels of chlorophyll (PAIVA NETO et al., 2013).

Table 4. Mean chlorophyll A, B, and total levels $\left(\mu \mathrm{g} \mathrm{cm}^{-3}\right)$ for barueiro (Dipteryx alata Vog.) seedlings in three nutrient culture media and four doses of activated charcoal during in vitro establishment.

\begin{tabular}{cccc}
\hline Nutrient Medium & Chlorophyll A & Chlorophyll B & Chlorophyll Total \\
\hline AA & $44.86 \mathrm{~A}$ & $22.02 \mathrm{AB}$ & $66.86 \mathrm{AB}$ \\
MS & $44.95 \mathrm{~A}$ & $24.52 \mathrm{~A}$ & $69.48 \mathrm{~A}$ \\
WPM & $42.46 \mathrm{~B}$ & $18.57 \mathrm{~B}$ & $61.04 \mathrm{~B}$ \\
\hline
\end{tabular}

$\mathrm{CV}=14.28 \% ; \mathrm{LSD}=11.52$

Means followed by the same capital letter in a column do not differ by Tukey test at 5\% probability; CV: coefficient of variation; LSD: least significant difference.

Chlorophyll content is positively correlated with $\mathrm{N}$ content in plant and crop yields. This relationship is primarily attributable to the fact that 50 to $70 \%$ of the total $\mathrm{N}$ forms enzymes in the leaves that are associated with chloroplasts (REINBOTHE et al., 2010; SINGH et al., 2010). The nutritional WPM medium, for example, has $25 \%$ of the concentration of nitrate ions and ammonia of the MS medium (PASQUAL, 2001). This fact elucidates the reason chlorophyll contents is greater in the MS media, which provides more nitrogen and favours higher chlorophyll synthesis. This finding is contrary to the statement of Silva et al. (2012) that the chlorophyll concentration is correlated with the concentration of nitrogen in the plant, as well as crop productivity. Based on this principle, the chlorophyll index has been used not only during in vitro culture, but also in the management of fruit already installed in the field, such as citrus and pecan (HARDIN et al., 2012; SOUZA et al., 2011). Moreover, Paiva Neto et al. (2013) found that in vitro plantlets that have higher chlorophyll contents show higher survival rates and better development in the acclimatisation phase. This information emphasises the importance of evaluating the concentration of this molecule from the establishment phase of a species, to assist in the selection of the best protocol to be followed.
Based on these results, we conclude that MS was the best nutrient medium for barueiro and the most suitable for their in vitro establishment. Furthermore, addition of activated charcoal was shown to be essential for in vitro growth of barueiro, with $3 \mathrm{~g} \mathrm{~L}^{-1}$ the recommended concentration for the studied phase.

\section{Acknowledgements}

We thank the CNPq (National Council for Scientific and Technological Development) for the financial aid granted for this work.

\section{References}

ALMEIDA, C. S.; LÉDO, A. S.; ARAÚJO, A. G.; SILVA, A. V.; SILVA JÚNIOR, J. S.; SANTOS, J. E.; RIBEIRO, M. M. J.; VILANOVA NETA, J. L. Efeito do meio de cultura na germinação in vitro do jenipapeiro. Scientia Plena, Aracaju, v. 9, n. 10, p. 1-6, 2013.

ALMEIDA, S. P.; PROENÇA, C. E. B.; SANO, S. M.; RIBEIRO, J. F. Cerrado: espécies vegetais úteis. Planaltina: Embrapa, CPAC, 1998. 464 p.

ARDITTI, J.; ERNST, R. Micropropagation of orchids. New York: John Wiley, 1992. 682 p.

ASSIS, K. C.; PEREIRA, F. D.; CABRAL, J. S. R.; SILVA, F. G.; SILVA, J. V.; SANTOS, S. C. In vitro 
cultivation of Anacardium othonianum Rizz.: effects of salt concentration and culture medium volume. Acta Scientiarum. Agronomy, Maringá, v. 34, n. 1, p. 77-83, 2012.

BLUMENSCHEIN, A.; CALDAS, R. A. Projeto de domesticação de plantas do Cerrado e sua incorporação a sistemas produtivos regionais. Goiânia: Ed. UFG, $1995.91 \mathrm{p}$.

BONGA, J. M. Tissue culture techniques. In: BONGA, J. M.; DURZAN, D. J. Tissue culture in forestry. Dordrecht: Martinus Nijhoff, 1985. p. 4-35.

BOULAY, M. Aspects pratiques de la multiplication in vitro de essences forestiers. In: AFOCEL. Annales de Recherches Sylvicoles. Paris: Association ForetCellulose, 1964. p. 7-43.

CHAGAS, E. A.; PASQUAL, M.; RAMOS, J. D.; PIO, L. A. S.; DUTRA, L. F.; CAZETTA, J. O. Cultivo de embriões imaturos de citros em diferentes concentrações de carvão ativado e ácido giberélico. Ciência $e$ Agrotecnologia, Lavras, v. 29, n. 6, p. 1125-1131, 2005.

MARTINELLI, G.; MORAES, M. A. Livro vermelho da flora do Brasil. Rio de Janeiro: Andrea Jakobsson: Instituto de Pesquisas Jardim Botânico do Rio de Janeiro, 2013. $1100 \mathrm{p}$.

FALKER AUTOMAÇÃO AGRÍCOLA LTDA. Medidor eletrônico do teor de clorofila ClorofiLOG 1030. Porto Alegre: Falker Automação Agrícola, 2008. 33 p. Disponível em: <http://www.falker.com.br/produto download.php?id=4>. Acesso em: 12 fev. 2015.

FERMINO JÚNIOR, P. C. P.; PEREIRA, J. E. S. Germinação e propagação in vitro de cerejeira (Amburana acreana (Ducke) A.C. Smith - Fabaceae). Ciência Florestal, Santa Maria, v. 22, n. 1, p. 1-9, 2012.

FERREIRA, D. F. SISVAR: sistema de análise de variância. Versão 5.3. Lavras: UFLA, 2010. (Software estatístico)

GEORGE, E. F. Plant propagation by tissue culture. part 1 - the technology. Wilts: Exegetics Ltd. Edington, 1993. $574 \mathrm{p}$.

GEORGE, P. S.; RAVISHANKAR, G. A. In vitro multiplication of Vanilla planifolia using axillary bud explants. Plant Cell Reports, Berlin, v. 16, n. 6, p. 490495, 1997.

GOMES, G. A. C.; PAIVA, R.; HERRERA, R. C.; PAIVA, P. D. de O. Micropropagation of Maclura tinctoria L.: an endangered wood species. Revista Árvore, Viçosa, MG, v. 34, n. 1, p. 25-30, 2010.

GRATTAPAGLIA, D.; MACHADO, M. A. Micropropagação. In: TORRES, A. C.; CALDAS, L. S.;
BUSO, J. A. (Ed.). Cultura de tecidos e transformações genéticas de plantas. Brasília: Embrapa, SPI/Embrapa, CNPH, 1998. v. 1, p. 183-260.

HARDIN, J. A.; SMITH, M. W.; WECKLER, P. R.; CHEARY, B. S. In situ measurement of pecan leaf nitrogen concentration using a chlorophyll meter and vis-near infrared multispectral camera. Hortscience, Alexandria, v. 47, n. 7, p. 955-960, 2012.

JUNQUEIRA, N. T. V.; JUNQUEIRA, K. P.; PREREIRA, A. V.; PEREIRA, E. B. C.; BRAGA, M. F.; CONCEIÇÃO, L. D. H. C. S.; FALEIRO, F. G. Fruteiras nativas do cerrado: o extrativismo e a busca da domesticação. In: CONGRESSO BRASILEIRO DE FRUTICULTURA, 22., 2012, Bento Gonçalves. Anais... Bento Gonçalves: SBF, 2012.

KERBAUY, G. B. Fisiologia vegetal. Rio de Janeiro: Guanabara Koogan, 2004. 452 p.

LÉDO, A. S.; LAMEIRA, O. A.; BENBADIS, A. K. Explantes de cupuaçuzeiro submetidos a diferentes condições de cultivo in vitro. Revista Brasileira de Fruticultura, Jaboticabal, v. 24, n. 3, p. 604-607, 2002.

LÉDO, A. S.; SECA, G. S. V.; BARBOZA, S. B. S. C.; SILVA JÚNIOR, J. B. Crescimento inicial de mangabeira (Hancornia speciosa Gomes) em diferentes meios de cultivo in vitro. Ciência e Agrotecnologia, Lavras, v. 5, n. 4, p. 989-993, 2007.

LLOYD, G.; McCOWN, B. Commercially feasible micropropagation of montain laurel, Kalmia latifolia, by use of shoot tip culture. Combined Proceedings of the International Plant Propagator's, Carlisle, v. 30, n. 1, p. 421-327, 1981.

MALDANER, J.; NICOLOSO, F. T.; SANTOS, E. S.; FLORES, R.; SKREBSKY, E. C. Sacarose e nitrogênio na multiplicação in vitro de Pfaffia glomerata (Spreng.) Pedersen. Ciência Rural, Santa Maria, v. 36, n. 4, p. 1201-1206, 2006.

MURASHIGE, T.; SKOOG, F. A revised method for rapid growth and bioassays with tobacco tissue cultures. Physiologia Plantarum, Copenhagen, v. 15, n. 3, p. 473497, 1962.

PAIVA NETO, V. B.; CAMPOS, G. O.; BOARETTO, A. G.; ZUFFO, M. C. R.; TORREZAN, M. A.; BENETÃO, J. Comportamento in vitro de Aspasia variegata, uma orquídea epífita do cerrado brasileiro. Ciência Rural, Santa Maria, v. 43, n. 12, p. 2178-2184, 2013.

NUNES, C. F.; DALILHIA, M. P.; SANTOS, N.; CUSTÓDIO, T. N.; ARAÚJO, A. G. Diferentes suplementos no cultivo in vitro de embriões de pinhãomanso. Pesquisa Agropecuária Brasileira, Brasília, v. 43, n. 1, p. 9-14, 2008. 
OZYIGIT,I.I.;KAHRAMAN,M.V.;ERCAN,O. Relation between explant age, total phenols and regeneration response in tissue cultured cotton (Gossypium hirsutum L.). African Journal of Biotechnology, Istanbul, v. 6, n. 1, p. 3-8, 2007.

PAN, M. J.; STADEN, J. V. The use of charcoal in vitro culture-A review. Plant Growth Regulation, Berlin, v. 26, n. 3, p. 155-163, 1998.

PASQUAL, M. Textos acadêmicos: meios de cultura. Lavras: FAEPE/UFLA, 2001. 127 p.

PERES, L. E. P.; KERBAUY, G. B. Controle hormonal do desenvolvimento de raízes. Revista Universa, Brasília, v. 8, n. 1, p. 181-196, 2000.

REINBOTHE, C.; BAKKOURI, M.; BUHR, F.; MURAKI, N.; NOMATA, J.; KURISU, G.; FUJITA, Y. E.; REINBOTHE, S. Chlorophyll biosynthesis: spotlight on protochlorophyllide reduction. Trends in Plant Science, Oxford, v. 15, n. 11, p. 614-624, 2010.

RIBEIRO, V. G.; SANÁBIO, D.; SOUZA, C. N.; LOPES, P. S. N.; BOCARDO, M. R.; PASQUAL, M. Efeitos de ácido giberélico e carvão ativado no cultivo in vitro de Citrus limonia Osbeck x Poncirus trifoliata (L.) Raf. Pesquisa Agropecuária Brasileira, Brasília, v. 35, n. 1, p. 27-30, 2000.

RICCI, A. P.; MOURÃO FILHO, F. D. A. A.; MENDES, B. M. J.; PIEDADE, S. M. D. S. Somatic embryogenesis in Citrus sinensis, $C$. reticulata and $C$. nobilis $\mathrm{x} C$. deliciosa. Scientia Agricola, Piracicaba, v. 59, n. 1, p. 4146, 2002.

ROCHA, J. P. Fatores genéticos e ambientais na emergência de plântulas de pequizeiro (Caryocar brasiliense camb.). 2009. Dissertação (Mestrado em Agronomia) - Universidade Federal dos Vales do Jequitinhonha e Mucuri, Diamantina.

RUSSOWSKI, D.; NICOLOSO, F. T. Nitrogênio e fósforo no crescimento de plantas de Ginseng Brasileiro [Pfaffia glomerata (Spreng.) Pedersen] cultivadas in vitro. Ciência Rural, Santa Maria, v. 33, n. 1, p. 57-63, 2003.

SANTANA, J. R. F.; PAIVA, R.; SOUZA, A. V.; OLIVEIRA, L. M. Effect of different culture tube caps and concentrations of activated charcoal and sucrose on in vitro growth and budding induction of Annona glabra L. Ciência e Agrotecnotogia, Lavras, v. 35, n. 5, p. 916$923,2011$.

SANTOS-SEREJO, J.; JUNGHANS, T. G.; SOARES, T. L.; SILVA, K. M. Meios Nutritivos para micropropagação de plantas. In: SOUZA, A. S.; JUNGHANS, T. G. Introdução à micropropagação de plantas. Cruz das
Almas: Embrapa Mandioca e Fruticultura Tropical, 2006. cap. 4, p. 80-98.

SATO, A. Y.; DIAS, H. C. T.; ANDRADE, L. A.; SOUZA, V. C. Micropropagação de Celtis sp.: controle da contaminação e oxidação. Cerne, Lavras, v. 7, n. 2, p. 117-123, 2001.

SCHNEIDERS, D.; PESCADOR, R.; BOOZ, M. R.; SUZUKI, R. M. Germinação, crescimento e desenvolvimento in vitro de orquídeas (Cattleya spp., Orchidaceae). Revista Ceres, Viçosa, MG, v. 59, n. 2, p. 185-191, 2012.

SILVA, A. L. L.; GOLLO, A. L; BRONDANI, G. E.; HORBACH, M. A.; OLIVEIRA, L. S.; MACHADO, M. P.; LIMA, K. K. D.; COSTA, J. L. Micropropagation of Eucalyptus saligna Sm. from cotyledonary nodes. Pakistan Journal of Botany, Pakistan, v. 47, n. 1, p. 311318, 2015.

SILVA, M.; MANNIGEL, A. R.; MUNIZ, A. S.; PORTO, S. M. A.; MARCHETTI, M. E.; NOLLA, A.; BERTANI, R. M. A. Ammonium sulphate on maize crops under no tillage. Bragantia, Campinas, v. 71, n. 1, p. 90-97, 2012.

SILVÉRIO, M. D. O.; CASTRO, C. F. S.; MIRANDA, A. R. Avaliação da atividade antioxidante e inibitória da tirosinase das folhas de Dipteryx alata Vogel (Baru). Revista Brasileira de Plantas Medicinais, Botucatu, v. 15, n. 1, p. 59-65, 2013.

SINGH, V.; SINGH, B.; SINGH, Y.; THIND, H. S.; GUPTA, R. K. Need based nitrogen management using the chlorophyll meter and leaf colour chart in rice and wheat in South Asia: a review. Nutrient Cycling Agroecosyst, Dordrecht, v. 88, n. 3, p. 361-380, 2010.

SOUZA, T. R.; SALOMÃO, L. C.; ANDRADE, T. F.; BÔAS, R. L. V.; QUAGGIO, J. A. Medida indireta da clorofila e sua relação com o manejo da adubação nitrogenada em plantas cítricas fertirrigadas. Revista Brasileira de Fruticultura, Jaboticabal, v. 33, n. 3, p. 993-1003, 2011.

STEIN, V. C.; PAIVA, R.; SOARES, F. P.; NOGUEIRA, R. C.; SILVA, L. C.; EMRICH, E. Germinação in vitro e ex vitro de Inga vera Willd. subsp. affinis (DC.) T.D. Penn. Ciência e Agrotecnologia, Lavras, v. 31, n. 6, p. 1702-1708, 2007.

TAIZ, L.; ZEIGER, E. Fisiologia vegetal. Porto Alegre: Artmed, 2004. $722 \mathrm{p}$.

VAN WINKLE, S.; JOHNSON, S.; PULLMAN, G. $\mathrm{S}$. The impact of gelrite and activated carbon on the elemental composition of plant tissue culture media. Plant Cell Reports, New York, v. 21, n. 12, p. 1175-1182, 2003. 
